\title{
JBIR-65, a new diterpene, isolated from a sponge- derived Actinomadura sp. SpB081030SC-15
}

\author{
Motoki Takagi ${ }^{1}$, Keiichiro Motohashi ${ }^{1}$, Shams Tabrez Khan ${ }^{1}$, Junko Hashimoto ${ }^{1}$ and Kazuo Shin-ya ${ }^{2}$
}

The Journal of Antibiotics (2010) 63, 401-403; doi:10.1038/ja.2010.61; published online 16 June 2010

Keywords: Actinomadura; diterpene; marine sponge; radical scavenger

\begin{abstract}
Marine microorganisms, particularly, marine actinomycetes, are one of the most important resources for new biologically active metabolites, ${ }^{1}$ and in fact, many new compounds have been isolated from sponge-derived actinomycetes. ${ }^{2-4}$ We have recently discovered novel compounds, namely the anthracyclines tetracenoquinocin and 5 -iminoaranciamycin, ${ }^{5}$ a teleocidin JBIR- $31,{ }^{6}$ the tetrapeptides JBIR34 and JBIR-35, ${ }^{7}$ the isoprenoids JBIR-46, JBIR-47, JBIR $48^{8,9}$ and a new salicylamide JBIR-58. ${ }^{10}$ Our intention was to support the idea that new species are capable of producing unique metabolites. For this purpose, we isolated new species of actinomycetes from marine sponges and then searched for secondary metabolites in the culture of isolated strains. In this study, we isolated a new species (SpB081030SC-15) of Actinomadura from an unidentified marine sponge and purified a new diterpene compound designated as JBIR65 (1, Figure 1a) from the fermentation broth of Actinomadura sp. SpB081030SC-15. In this study, we report the fermentation procedure to obtain 1 and its subsequent isolation, structure elucidation and, in brief, its biological activities.
\end{abstract}

Actinomadura sp. SpB081030SC-15 was isolated from an unidentified marine sponge collected offshore of Ishigaki Island, Okinawa Prefecture, Japan. To identify the species of the strain SpB081030SC-15, we compared its $16 \mathrm{~S}$ ribosomal RNA gene sequences (Accession No. AB123566) with those available in the DNA Data Bank of Japan using a basic local alignment search tool. ${ }^{11}$ The strain was identified as a new species of the genus Actinomadura because comparison of its 16 S ribosomal RNA gene sequence revealed a low sequence similarity of $98 \%$ with Actinomadura nitritigenes (AB364595).

The strain SpB081030SC-15 was cultivated in 50-ml test tubes each containing $15 \mathrm{ml}$ of a seed medium consisting of starch (Kosokagaku, Tokyo, Japan) 1.0\%, polypeptone (Nihon Pharmaceutical, Tokyo, Japan) 1.0\%, molasses (Dai-Nippon Meiji Sugar, Tokyo, Japan) $1.0 \%$ and meat extract 1.0\% (Extract Ehlrich, Wako Pure Chemical Industry, Osaka, Japan), pH 7.2 (adjusted before sterilization). The seed culture in test tubes was agitated on a reciprocal shaker ( 355 r.p.m.) at $27^{\circ} \mathrm{C}$ for 2 days. Aliquots $(2.5 \mathrm{ml})$ of the broth were transferred to $500-\mathrm{ml}$ baffled Erlenmeyer flasks containing $100 \mathrm{ml}$ of a production medium consisting of glycerin $2.0 \%$, molasses $1.0 \%$, casein $0.5 \%$ and $\mathrm{CaCO}_{3} 0.4 \%, \mathrm{pH} 7.2$ (adjusted before sterilization) and cultured on a rotary shaker (180 r.p.m.) at $27^{\circ} \mathrm{C}$ for 5 days.

The mycelia in the fermentation broth (21) was separated by centrifugation and then extracted with $80 \%$ acetone. The extract was evaporated in vacuo to remove the acetone, and the aqueous residue was extracted with EtOAc. The organic layer was dried over $\mathrm{Na}_{2} \mathrm{SO}_{4}$ and evaporated to dryness. The residue $(700 \mathrm{mg}$ ) was subjected to normal-phase medium-pressure liquid chromatography (Purif-Pack SI-60, Moritex, Tokyo, Japan) and eluted with a gradient system of $n$-hexane-EtOAc $\left(0-30 \%\right.$ EtOAc) and $\mathrm{CHCl}_{3}-\mathrm{MeOH}$ $(0-50 \% \mathrm{MeOH})$, successively. The $3 \% \mathrm{MeOH}$-eluted fraction (50.1 mg) was further purified by preparative reverse-phase HPLC using an L-column 2 column (20 i.d. $\times 150 \mathrm{~mm}$; Chemical Evaluation and Research Institute, Tokyo, Japan) with $60 \% \mathrm{MeOH}-\mathrm{H}_{2} \mathrm{O}$ containing $0.1 \%$ formic acid (flow rate: $\left.10 \mathrm{ml} \cdot \mathrm{min}^{-1}\right)$ to yield $1(0.22 \mathrm{mg}$, retention time $15.5 \mathrm{~min}$ ).

Compound 1 was isolated as a colorless oil $\left([\alpha]_{\mathrm{D}}{ }^{25}-90.0, c 0.1\right.$, $\mathrm{MeOH})$ that yielded an $[\mathrm{M}+\mathrm{H}]+{ }^{+}$ion at $m / z 317.1736$ in $\mathrm{HR}$ electrospray ionization-MS spectra consistent with the molecular formula $\mathrm{C}_{19} \mathrm{H}_{24} \mathrm{O}_{4}$ (calcd for $\mathrm{C}_{19} \mathrm{H}_{25} \mathrm{O}_{4}, 317.1753$ ). The IR absorption $(\mathrm{KBr}) v_{\max }$ at 3360 and $1660 \mathrm{~cm}^{-1}$ showed the presence of hydroxyl and quinone functional groups in $\mathbf{1}$. Direct connectivity between protons and carbons was established by analysis of the heteronuclear single quantum coherence spectrum, and the tabulated ${ }^{13} \mathrm{C}$ and ${ }^{1} \mathrm{H}$ NMR spectral data for $\mathbf{1}$ are shown in Table 1 . The analyses of doublequantum filtered (DQF)-COSY and heteronuclear multiple-bond correlation spectra revealed the structure of $\mathbf{1}$ (Figure $1 \mathrm{~b}$ ). Correlations between olefinic protons $15-\mathrm{H}\left(\delta_{\mathrm{H}} 5.75\right)$ and $16-\mathrm{H}\left(\delta_{\mathrm{H}} 4.85\right.$ and 4.92$)$

\footnotetext{
${ }^{1}$ Biomedicinal Information Research Center (BIRC), Japan Biological Informatics Consortium (JBIC), 2-4-7 Aomi, Koto-ku, Tokyo, Japan and ${ }^{2}$ Biomedicinal Information Research Center (BIRC), National Institute of Advanced Industrial Science and Technology (AIST), 2-4-7 Aomi, Koto-ku, Tokyo, Japan

Correspondence: Dr M Takagi, Biomedicinal Information Research Center (BIRC), Japan Biological Informatics Consortium (JBIC), 2-4-7 Aomi, Koto-ku, Tokyo 135-0064, Japan. E-mail: motoki-takagi@aist.go.jp or Dr K Shin-ya, Biomedicinal Information Research Center (BIRC), National Institute of Advanced Industrial Science and Technology (AIST), 2-4-7 Aomi, Koto-ku, Tokyo 135-0064, Japan.

E-mail: k-shinya@aist.go.jp
}

Received 21 March 2010; revised 7 May 2010; accepted 24 May 2010; published online 16 June 2010 
a<smiles>C=CC1(F)CCC2=C(C1)C(=O)CC1C(CO)=CC(=O)C(O)C21C</smiles>

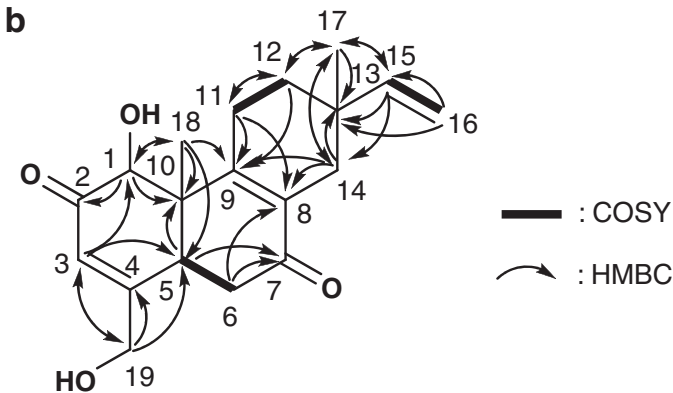

Figure 1 (a) Structure of JBIR-65 (1). (b) Key correlations in doublequantum filtered-COSY (bold lines) and heteronuclear multiple-bond correlation (HMBC) (arrows) spectra of $\mathbf{1}$.

Table $1{ }^{1} \mathrm{H}$ and ${ }^{13} \mathrm{C}$ NMR spectral data for JBIR-65 (1)

\begin{tabular}{lrl}
\hline & \multicolumn{1}{c}{1} \\
\cline { 2 - 3 } Position & \multicolumn{1}{c}{${ }^{13} \mathrm{C}$} & ${ }^{1} \mathrm{H}(\mathrm{J}$ in Hz$)$ \\
\hline 1 & 78.2 & $4.28, \mathrm{~s}$ \\
2 & 199.2 & \\
3 & 120.4 & $6.45, \mathrm{br} \mathrm{s}$ \\
4 & 165.1 & \\
5 & 42.0 & $3.39, \mathrm{dd}(13.8,4.5)$ \\
6 & 34.5 & $2.78, \mathrm{dd}(17.9,4.5), 2.61, \mathrm{dd}(13.8,17.9)$ \\
7 & 197.4 & \\
8 & 130.1 & \\
9 & 165.4 & \\
10 & 49.0 & \\
11 & 27.0 & $2.71, \mathrm{~m}$ \\
12 & 33.2 & $1.52, \mathrm{~m}$ \\
13 & 33.9 & \\
14 & 33.2 & $2.46, \mathrm{~d}(17.9), 1.91, \mathrm{~d}(17.9)$ \\
15 & 146.4 & $5.75, \mathrm{dd}(17.4,10.8)$ \\
16 & 110.3 & $4.85^{\mathrm{a}}, 4.92, \mathrm{dd}(10.8,1.0)$ \\
17 & 25.2 & $1.02, \mathrm{~s}$ \\
18 & 12.0 & $0.98, \mathrm{~s}$ \\
19 & 61.5 & $4.25, \mathrm{br} \mathrm{s}$ \\
\hline & &
\end{tabular}

${ }^{13} \mathrm{C}(125 \mathrm{MHz})$ and ${ }^{1} \mathrm{H}(500 \mathrm{MHz}) \mathrm{NMR}$ spectra were obtained on an NMR System $500 \mathrm{NB} \mathrm{CL}$ (Varian, Palo Alto, $\mathrm{CA}, \mathrm{USA}$ ) in $\mathrm{CD}_{3} \mathrm{OD}$, and the solvent peak was used as an internal standard $\left(\delta_{\mathrm{C}} 49.0, \delta_{\mathrm{H}} 3.20\right)$ $\left(\delta_{\mathrm{C}} 49.0, \delta_{\mathrm{H}} 3.20\right)$
aOverlapping.

and between methylene protons $11-\mathrm{H}\left(\delta_{\mathrm{H}} 2.71\right)$ and $12-\mathrm{H}\left(\delta_{\mathrm{H}} 1.52\right)$, respectively, were observed in the DQF-COSY spectrum. The ${ }^{1} \mathrm{H}^{-13} \mathrm{C}$ long-range couplings between a singlet methyl proton $17-\mathrm{H}\left(\delta_{\mathrm{H}} 1.02\right)$ and a quaternary carbon $\mathrm{C}-13\left(\delta_{\mathrm{C}} 33.9\right)$, methylene carbons $\mathrm{C}-12$
$\left(\delta_{\mathrm{C}} 33.2\right)$ and $\mathrm{C}-14\left(\delta_{\mathrm{C}} 33.2\right)$ and an olefinic carbon $\mathrm{C}-15\left(\delta_{\mathrm{C}} 146.4\right)$ revealed the connectivity between $\mathrm{C}-11\left(\delta_{\mathrm{C}} 27.0\right), \mathrm{C}-12, \mathrm{C}-13, \mathrm{C}-14$, $\mathrm{C}-15$ and $\mathrm{C}-17\left(\delta_{\mathrm{C}} 25.2\right)$. Furthermore, ${ }^{1} \mathrm{H}^{-13} \mathrm{C}$ long-range couplings between $11-\mathrm{H}$ and methylene proton $14-\mathrm{H}\left(\delta_{\mathrm{H}} 1.91\right.$ and 2.46) and olefinic quaternary carbons C-8 $\left(\delta_{\mathrm{C}} 130.1\right)$ and C-9 $\left(\delta_{\mathrm{C}} 165.4\right)$ and homoallylic coupling between $11-\mathrm{H}$ and $14-\mathrm{H}$ proved the existence of a 4-methyl-4-vinylcyclohex-1-ene moiety.

A correlation between a methine proton $5-\mathrm{H}\left(\delta_{\mathrm{H}} 3.39\right)$ and methylene protons $6-\mathrm{H}\left(\delta_{\mathrm{H}} 2.61\right.$ and 2.78) was observed in the DQF-COSY spectrum. The ${ }^{1} \mathrm{H}^{-13} \mathrm{C}$ long-range couplings from a singlet methyl proton $18-\mathrm{H}\left(\delta_{\mathrm{H}} 0.98\right)$ to an oxymethine carbon C-1 $\left(\delta_{\mathrm{C}} 78.2\right)$, a quaternary carbon $\mathrm{C}-10\left(\delta_{\mathrm{C}} 49.0\right)$, C-9 and a methine carbon $\mathrm{C}-5\left(\delta_{\mathrm{C}} 42.0\right)$, whose methine proton $5-\mathrm{H}$ was in turn longrange coupled to an $\alpha, \beta$-unsaturated ketone carbonyl carbon C-7 $\left(\delta_{\mathrm{C}}\right.$ 197.4) and C-8, revealed the presence of an octalone substructure. A hydroxymethyl proton $19-\mathrm{H}\left(\delta_{\mathrm{H}} 4.25\right)$ was ${ }^{1} \mathrm{H}_{-}{ }^{13} \mathrm{C}$ long-range coupled to an olefinic methine carbon $\mathrm{C}-3\left(\delta_{\mathrm{C}} 120.4\right)$, olefinic quaternary carbon $\mathrm{C}-4\left(\delta_{\mathrm{C}} 165.1\right)$ and $\mathrm{C}-5$. The ${ }^{1} \mathrm{H}_{-}{ }^{13} \mathrm{C}$ long-range couplings between an olefinic methine proton $3-\mathrm{H}\left(\delta_{\mathrm{H}} 6.45\right)$ and $\mathrm{C}-1$ and between an oxymethine proton $1-\mathrm{H}\left(\delta_{\mathrm{H}} 4.28\right)$ and an $\alpha, \beta$-unsaturated ketone carbonyl carbon $\mathrm{C}-2\left(\delta_{\mathrm{C}} 199.2\right)$ established the presence of a six-membered moiety, as shown in Figure $1 \mathrm{~b}$. The ${ }^{13} \mathrm{C}$ NMR chemical shifts in the case of 1 resembled those in the case of 15 -isopimaradien-7-one ${ }^{12}$ and 2-oxo-18-hydroxy$10 \alpha, 17 \alpha, 19 \alpha, 20 \beta$-(-)-cleroda-3,13(16),14-triene, ${ }^{13}$ supporting the planar structure of $\mathbf{1}$, as shown in Figure 1a.

To evaluate the biological activity of $\mathbf{1}$, we conducted tests to evaluate its cytotoxic, antimicrobial and radical scavenging activities. The results showed that 1 protects neuronal hybridoma N18-RE-105 cells ${ }^{14-16}$ from L-glutamate toxicity with an $\mathrm{EC}_{50}$ value of $31 \mu \mathrm{M}$. However, this protective effect of 1 was weaker than that of the representative antioxidant $\alpha$-tocopherol ( $\mathrm{EC}_{50}$ value, $\left.6.3 \mu \mathrm{M}\right)$. It would be interesting to clarify the mode of action of 1 because its radical scavenging activity could not be determined on the basis of its chemical structure. The cytotoxic activity of $\mathbf{1}$ against several cancer cell lines was tested by the WST-8 (2-(2-methoxy-4-nitrophenyl)-3(4-nitrophenyl)-5-(2,4-disulfophenyl)-2H-tetrazolium, monosodium salt) colorimetric assay (Cell Counting Kit, Dojindo, Kumamoto, Japan). However, 1 showed no cytotoxicity even at a concentration of $50 \mu \mathrm{g} \mathrm{ml}^{-1}$ for $48 \mathrm{~h}$. In addition, 1 showed no antimicrobial activity against Micrococcus luteus, Escherichia coli and Candida albicans.

In conclusion, we isolated a new diterpene, JBIR-65 (1), from the strain SpB081030SC-15. Diterpenes have been isolated from many fungi and plants, however, few reports of the isolation of diterpenes from actinobacteria are available. To our knowledge, this is the first report of a diterpene compound isolated from the genus Actinomadura. This study suggests that new species of actinomycetes isolated from marine organisms have the potential to produce new bioactive compounds.

1 Fenical, W. \& Jensen, P. R. Developing a new resource for drug discovery: marine actinomycete bacteria. Nat. Cheml. Biol. 2, 666-673 (2006).

2 Lee, H. S. et al. Cyclic peptides of the nocardamine class from a marine-derived bacterium of the genus Streptomyces. J. Nat. Prod. 68, 623-625 (2005).

3 Mitova, M. I. et al. Evolving trends in the dereplication of natural product extracts. 2. The isolation of chrysaibol, an antibiotic peptaibol from a New Zealand sample of the mycoparasitic fungus Sepedonium chrysospermum. J. Nat. Prod. 71, 824-827 (2008).

4 Pimentel-Elardo, S. M., Gulder, T. A. M., Hentschel, U. \& Bringmann, G. Cebulactams $A 1$ and $A 2$, new macrolactams isolated from Saccharopolyspora cebuensis, the first obligate marine strain of the genus Saccharopolyspora. Tetrahedron Lett. 49, 6889-6892 (2008). 
5 Motohashi, K., Takagi, M. \& Shin-ya, K. Tetracenoquinocin and 5-iminoaranciamycin from a sponge-derived Streptomyces sp. Sp080513GE-26. J. Nat. Prod. 73, 755-758 (2010).

6 Izumikawa, M., Khan, S. T., Komaki, H., Takagi, M. \& Shin-ya, K. JBIR-31, a new teleocidin analog produced by a salt-requiring Streptomyces sp. NBRC 105896 isolated from a marine sponge. J. Antibiot. 63, 33-36 (2010).

7 Motohashi, K., Takagi, M. \& Shin-Ya, K. Tetrapeptides possessing a unique skeleton, JBIR-34 and JBIR-35, isolated from a sponge-derived actinomycete, Streptomyces sp. Sp080513GE-23. J. Nat. Prod. 73, 226-228 (2010).

8 Khan, S. T. et al. Distribution of the 3-hydroxyl-3-methylglutaryl coenzyme A reductase gene and isoprenoid production in marine-derived Actinobacteria. FEMS Microbiol. Lett. 304, 89-96 (2010).

9 Izumikawa, M., Khan, S. T., Takagi, M. \& Shin-ya, K. Sponge-derived Streptomyces producing isoprenoids via the mevalonate pathway. J. Nat. Prod. 73, 208-212 (2010).

10 Ueda, J., Khan, S. T., Takagi, M. \& Shin-ya, K. JBIR-58, a new salicylamide derivative, isolated from a marine sponge-derived Streptomyces sp SpD081030ME-02. J. Antibiot. 63, 267-269 (2010).
11 Altschul, S. F., Gish, W., Miller, W., Myers, E. W. \& Lipman, D. J. Basic local alignment search tool. J. Mol. Biol. 215, 403-410 (1990).

12 Asili, J. et al. Labdanes and isopimaranes from Platycladus orientalis and their effects on erythrocyte membrane and on Plasmodium falciparum growth in the erythrocytehost cells. J. Nat. Prod. 67, 631-637 (2004).

13 Khan, M. R., Gray, A. I., Sadler, I. H. \& Waterman, P. G. Clerodane diterpenes from Casearia corymbosa stem bark. Phytochemistry 29, 3591-3595 (1990).

$14 \mathrm{Kim}, \mathrm{W}$. G. et al. New diphenazines with neuronal cell protecting activity, phenazostatins A and B, produced by Streptomyces sp. J. Antibiot. 50, 715-721 (1997).

15 Shin-ya, K., Shimizu, S., Kunigami, T., Furihata, K. \& Seto, H. A new neuronal cell protecting substance, lavanduquinocin, produced by Streptomyces viridochromogenes. J. Antibiot. 48, 574-578 (1995).

16 Ueda, J., Hashimoto, J., Inaba, S., Takagi, M. \& Shin-ya, K. JBIR-59, a new sorbicillinoid, from a marine-derived fungus Penicillium citrinum Spl080624G1f01. J. Antibiot. 63, 203-205 (2010). 